\title{
The relationship between the willingness of buying counterfeit goods and consumer personality traits
}

\author{
Sheng Jun ${ }^{1}$ Song Liang ${ }^{2}$ Wang Qiong ${ }^{2}$ Wang Jian ${ }^{2}$ \\ ${ }^{\mathbf{1}}$ Doctor of Business Administration Assistant professor in Business School, Guilin University of \\ Electronic technology \\ 2 Business School, Guilin University of Electronic technology \\ (114264786@qq.com; 619171950@qq.com; 646142698@qq.com; 283366592@qq.com)
}

\begin{abstract}
In the situation that the economic globalization is keeping improving, counterfeit goods has become a worldwide problem. Counterfeiting is now widely regarded as a seriously social, economic, and political issue. The majority of researches on counterfeiting have tended to focus on issues of supply. This paper stood in the side of counterfeits of home-textile to explore the relationship between willingness to buy counterfeit goods and consumer personality traits. Through studying on the undergraduate on campus which would like to purchase counterfeit goods, we found that it is the values of materialism, consumer ethical beliefs, consumer vanity characteristics and attitudes towards counterfeiting that would have significant impact on the consumer's willingness to buy counterfeit goods.
\end{abstract}

Keywords: willingness to buy counterfeit goods, the values of Materialism, Consumer ethical beliefs, Vanity characteristics

\section{Introduction}

Counterfeit goods (sometimes colloquially referred to 'knock-offs') refer to every kinds of unauthorized product that infringes upon intellectual property rights (brand names, patents, trademarks, and copyrights).[1] Counterfeit goods do great harm on social economic including unemployment, tax revenue and price of quality goods. It has the worst impact brought by counterfeit goods in China among the other countries in the world.

According to the estimated result of China's state council reform and development commission that China is full of fake goods added up to $\$ 19$ billion to $\$ 24$ billion in the early year of 2001 in the market, however, the data seriously underestimated the seriousness of the counterfeit goods. Some famous brand owners estimated that counterfeit goods had taken up almost 15\%-20\% market-share in China. Every year Microsoft loses nearly $\$ 10$ billion due to software piracy.[2]

Because we find it so difficulty to get accurate statistics that those figures can't be confirmed. The conduct of counterfeiting is generally regarded as a seriously social, economic, and political problem. For example, studies have shown that counterfeit goods lowers consumers' confidence in legitimate brands and company reputations, impacts upon consumers' perceptions of genuine articles, and poses potential threat to consumer health and safety. Moreover, the problem of counterfeiting now has been identified in almost every field of major production, from computer software to prescription drugs.

Given the widespread effects of counterfeit goods, it comes as bad news that there is little literature on the field of counterfeit goods, particularly short of those related to consumers' willingness to buy counterfeit goods. Although consuming of counterfeit goods is so common, the research of this aspect is extremely rare in China, especially from the angle of consumers' intention to 
purchase counterfeit goods. There always are some consumers owning more preference to buy counterfeit goods in contrast with others. For example, some consumers bought the low-cost generic Rolex, a CD or even counterfeit medicines without hesitation,[3] but in the same time the other people never thought about the possibility of buying counterfeit goods. This phenomenon needs academia to be worth to explore.

Even if the government and enterprise control counterfeit sales through the various measures in short time, because of the existence of counterfeit market demanding, consumers will also look for counterfeit goods through all kinds of channels. In the conclusion, we need to research counterfeit market from the perspective of consumers.

In this study, we mainly explore the relationship between the willingness to buy counterfeit goods and consumers' personality traits.

At first, we examined whether attitudes towards counterfeiting would significantly predict consumers' intention to buy counterfeit goods or not.

There are many studies related to attitudes towards counterfeiting as well as the purchase intention, but the measuring of counterfeit attitude has used different scale and dimension.Most of the researches reveals that consumers' intention has the very strong predictive impact on the consumer's conduct of buying counterfeit goods.Albers-Miller , Nancy D . Kwong et al, Wang et al, Penz all of their studies show that it is consumers' attitude towards counterfeiting that is positively correlated to purchase intention .[4][5][6][7]

We used Attitudes towards Counterfeiting Scale which is developed by Furnham and Valgeirsson .8 The latter is a three-factor scale which included measuring attitudes towards law about counterfeiting, the value of counterfeit products, and previous experience of buying counterfeit goods. In their studies, Furnham and Valgeirsson demonstrated that each of these three factors can significantly predict the willingness to buy 15 types of counterfeit goods.[8] This research proposes the following hypothesis:

H1a Consumers' attitudes towards law and order in respect of counterfeiting have a negative relationship with intention to buy $y$ counterfeit goods.
H1b The value of counterfeit products have a positive relationship with intention to buy counterfeit goods.

H1c Previous experience of buying counterfeit goods have a positive relationship with intention to buy counterfeit goods.

Secondly, we examined the association of an individual's materialism values (that is, in pursuit of material objects at the expense of mental or spiritual aspects of life) with intention to buy counterfeit goods. About the research of consumer materialism values, Furnham and Valgeirsson found that consumer materialism values have positive correlation with intention to buy counterfeit goods.8But the conclusion of Wee et al's research is that materialism values have no relationship with consumers purchase intention.[9]

In this study we used Richins Material Value Scale. The latter measures materialism along three-dimensions, namely acquisition centrality (describes the extent to which possessions are placed in the centre of one's life), acquisition as the pursuit of happiness (the idea that possessions are essential for life satisfaction and well-being), and possession-defined success (the extent to which people judge themselves and others by the number and quality of possessions accumulated))[10]. This research proposes the following hypothesis:

$\mathrm{H} 2 \mathrm{a}$ acquisition centrality have a positive relationship with intention to buy counterfeit goods.

$\mathrm{H} 2 \mathrm{~b}$ acquisition as the pursuit of happiness have a positive relationship with intention to buy counterfeit goods.

$\mathrm{H} 2 \mathrm{c}$ possession-defined success have a positive relationship with intention to buy counterfeit goods.

Thirdly, we examined the association of an individual's consumer ethics with intention to buy counterfeit goods. As to the research of this subject, Wang, Tan, Moore's research conclusion is that if consumers have the higher moral intentions, the lower that consumers will purchase counterfeit goods, [11] [12] Amit Poddar, Jeff Foreman, Syagnik Banerjee, Pam Scholder Ellen Further research found that once consumer acquired the awareness of the high social evaluation of the producer's responsibility, consumers will also reduce the counterfeit goods of this enterprise's brand .[13] 
In this study we use Muncy and Vitell consumer ethics scale ,their scale have four dimension :(1)actively benefiting from illegal activities,(2)passively benefiting, (3) actively benefiting from deceptive ( or questionable, but legal) practices, and(4)no harm/nofoul activities.[14] this research proposes the following hypothesis.

H3a:actively benefiting from illegal activities have a positive relationship with intention to buy counterfeit goods.

H3b:passively benefiting have a positive relationship with intention to buy counterfeit goods.

H3c:ctively benefiting from deceptive practices have a positive relationship with intention to buy counterfeit goods.

H3d:no harm activities have a positive relationship with intention to buy counterfeit goods.

Fourthly, we will explore the association of consumer vanity characteristics with intention to buy counterfeit goods. Vanity trait is a feature of psychology which referred to the willing of having a certain honor that in fact they don't or cannot have, but showing particularly that as if having some kind of honor personality through words and deeds.

In the measurement of vanity characteristics, we used vanity characteristics scale of Netemeyer, Burton and Lichtenstein e. This scale contains two dimensions involving appearance care and achievement care. This research proposes the following hypothesis:

H4a: consumer appearance care have a positive relationship with intention to buy counterfeit goods

H4b: consumer achievement care have a positive relationship with intention to buy counterfeit goods

Regarding to intention to buy counterfeit goods, we adopted the undergraduates as the research objects. In the study, eight kinds of counterfeit goods, which is the main counterfeit goods college students often buy, are research objects. They respectively are shoes, clothes, watches, mobile phones, bags, handbags wallet backpack, electronic products, computer software.

\section{Method}

\subsection{Exploratory factor analysis}

The scale of the questionnaire used is mature scale, and even some scales haven't been used in domestic, so before the formal questionnaire survey is proceeding, we need to purify the factor.

First we use exploratory factor analysis and principal component analysis. Taking the characteristic values greater than 1 as the principle of selecting factor, and then using the biggest variation as a method for orthogonal axis. Keep the item which factor loading absolute value greater than 0.5 . According to the purification of the results, in a formal scale, consumer attitude scale has seven-items, Materialism scale has ten-items, and vanity characteristics have nine-item items.

Muncy and Vitell consumer ethics scale , have four dimension :(1)actively benefiting from illegal activities,(2)passively benefiting,(3)actively benefiting from deceptive ( or questionable, but legal) practices and(4)no harm/no foul activities. But in using of the data we were able to have the exploratory factor analysis. It was found that Chinese consumers' ethic contains merely three types, passively benefiting and actively benefiting from deceptive can be combined into one factor that is benefiting behavior factor. ( Table1) This is consistent with Taiwan scholar Lu Long-quan's research which is about consumer ethic belief.[15] So in the next study, we merge $\mathrm{H} 3 \mathrm{~b}$ and $\mathrm{H} 3 \mathrm{c}$ into one research hypothesis that the benefiting behavior has a positive relationship with intention to buy counterfeit goods.

As to intention to buy counterfeit goods, we extract two factors. Through the table we can see that we can extract the first factor from the first seven commodities, and extract the second factor from the computer software which as a unique goods .( Table2) This means the first seven goods have uniform willingness to buy counterfeit goods but computer software purchasing intention don't. This may due to the characteristics of counterfeit software, because price gap is too big between original software and piracy software in China. In the situation of the other factors remaining unchanged, the willing that is consumers to buy pirated software is too strong to make the pirated software purchasing intention be not representative. So in formal research process 
we will kick the counterfeit software out the scope of study.

\begin{tabular}{|c|c|c|c|}
\hline \multicolumn{4}{|c|}{ Rotated Component Matrixa } \\
\hline & \multicolumn{3}{|c|}{ Component } \\
\hline & $\begin{array}{l}\text { actively } \\
\text { benefiting } \\
\text { from illegal } \\
\text { activities, }\end{array}$ & $\begin{array}{l}\text { benefiting } \\
\text { behavior }\end{array}$ & $\begin{array}{c}\text { No harm/nofoul } \\
\text { activities }\end{array}$ \\
\hline $\begin{array}{l}\text { Xiao Qiang return the goods damaged by him, but he tell businessman } \\
\text { what he bought is defective goods, do you think he }\end{array}$ & .113 & .759 & .116 \\
\hline $\begin{array}{l}\text { Xiao Qiang eat furtively in the super market, but he don't pay money . } \\
\text { do you think he }\end{array}$ & .181 & .834 & -.017 \\
\hline Xiao Qiang lies about commodity prices to clerk, do you think he & .342 & .788 & -.016 \\
\hline $\begin{array}{l}\text { Xiao Qiang kept silent when he find clerk give more change in } \\
\text { check-out, do you think he }\end{array}$ & .599 & .577 & -.043 \\
\hline $\begin{array}{l}\text { Xiao Qiang keep silent when clerk miscalculate the age give } \\
\text { preferential price to children, do you think he }\end{array}$ & .797 & .244 & -.043 \\
\hline $\begin{array}{l}\text { Xiao Qiang find more money in his own account, but don't ask it's } \\
\text { source. do you think he }\end{array}$ & .751 & .201 & .098 \\
\hline $\begin{array}{l}\text { Xiao Qiang lies about her children age , and obtain preferential price } \\
\text { when buying tickets, do you think he }\end{array}$ & .739 & .304 & .123 \\
\hline Xiao Qiang use expired coupon for shopping, do you think he & .759 & .161 & .204 \\
\hline $\begin{array}{l}\text { Xiao Qiang lie about price to bargain when buying the phone. do you } \\
\text { think he }\end{array}$ & .632 & .008 & .441 \\
\hline $\begin{array}{l}\text { Xiao Qiang don't buy clothes after trying on for an hour, do you think } \\
\text { he }\end{array}$ & .296 & .148 & .507 \\
\hline Xiao Qiang return the commodity that he don't like. do you think he & .101 & -.098 & .832 \\
\hline Xiao Qiang only read in bookstore but never buy. do you think he & -.023 & .044 & .816 \\
\hline
\end{tabular}

Table 1: Consumer ethical beliefs factor analysis results 


\begin{tabular}{|l|c|c|}
\hline & \multicolumn{2}{|c|}{ Component } \\
\hline & 1 & 2 \\
\hline electronic products & .540 & .415 \\
\hline shoes & .821 & .044 \\
\hline clothes & .825 & .090 \\
\hline watch & .530 & .458 \\
\hline Mobile phone & .655 & .187 \\
\hline luggage & .737 & .258 \\
\hline Handbags wallet backpack & .686 & .163 \\
\hline software & -.014 & .907 \\
\hline
\end{tabular}

Table 2: Consumers purchase intention factor analysis results

\section{2. scale}

The formal research is the questionnaire which is based on the scale that is already purified through exploratory analysis. All the scale used Likert5 level measurement scales, 5 is for the totally agree, 1 is for disagree completely.

\subsection{Participants}

All participants were undergraduates from one university in Anhui province and 280 questionnaires were issued. After questionnaire were collected, the author carefully checked the questionnaire and deleted questionnaire which is not standard.. The effective questionnaire was a total of 228 copies. The effective rate was $81.43 \%$. Among them, 122 are boys, 106 are girls.

\section{4. reliability and validity}

We use the Cronbach a value to test scale reliability. Except acquisition centrality and Previous experience of buying counterfeit goods, the Cronbach a value of other factors were greater than 0.7 . This means that the reliability is better, the scale of the internal consistency is better.

We used application confirmatory factor analysis method to inspect the validity of the scale, and through calculation, the model of the variables confirmatory factor analysis fit well. (Table 3 ) Factor A V E value are greater than 0.5 , the combination of various latent variables reliability are greater than 0.60 , its convergence validity meets the requirement. AVE square root is more than the correlation coefficients among two factors, it shows the discriminant validity meets the requirement.

(Table4)

\begin{tabular}{|c|c|c|c|c|c|c|c|}
\hline & & mean & $\begin{array}{l}\text { Standard } \\
\text { deviation }\end{array}$ & reliability & $\begin{array}{c}\text { Combination } \\
\text { reliability }\end{array}$ & AVE & $\begin{array}{c}\text { Cumulative } \\
\text { explained } \\
\text { variance }\end{array}$ \\
\hline \multirow{3}{*}{$\begin{array}{l}\text { consumer } \\
\text { materialism } \\
\text { values }\end{array}$} & $\begin{array}{l}\text { possession-defined } \\
\text { success }\end{array}$ & 8.9254 & 2.25640 & 0.704 & 0.7529 & 0.505 & \multirow{3}{*}{51.437} \\
\hline & $\begin{array}{l}\text { acquisition as the } \\
\text { pursuit of happiness }\end{array}$ & 11.4561 & 3.17102 & 0.759 & 0.799 & 0.501 & \\
\hline & acquisition centrality & 7.9035 & 1.98439 & 0.687 & 0.7448 & 0.4934 & \\
\hline \multirow[t]{2}{*}{$\begin{array}{l}\text { consumer } \\
\text { ethics }\end{array}$} & $\begin{array}{l}\text { actively benefiting } \\
\text { from illegal } \\
\text { activities }\end{array}$ & 4.9474 & 1.99047 & 0.773 & 0.8366 & 0.6309 & \multirow[t]{2}{*}{64.27} \\
\hline & benefiting behavior & 14.0526 & 4.31030 & 0.857 & 0.8623 & 0.5133 & \\
\hline
\end{tabular}




\begin{tabular}{|c|c|c|c|c|c|c|c|}
\hline & no harm activities & 9.0439 & 1.80010 & 0.713 & 0.7703 & 0.5384 & \\
\hline \multirow{2}{*}{$\begin{array}{l}\text { vanity } \\
\text { characteristics }\end{array}$} & appearance care & 11.6711 & 2.94017 & 0.763 & 0.8405 & 0.572 & \multirow{2}{*}{56.187} \\
\hline & achievement care & 17.9956 & 3.49890 & 0.782 & 0.8425 & 0.5175 & \\
\hline \multirow[t]{3}{*}{$\begin{array}{l}\text { attitudes } \\
\text { towards } \\
\text { counterfeiting }\end{array}$} & $\begin{array}{l}\text { Consumers' } \\
\text { attitudes towards } \\
\text { law and order }\end{array}$ & 9.7368 & 2,58103 & 0.779 & 0.8613 & 0.675 & \multirow{3}{*}{65.694} \\
\hline & $\begin{array}{l}\text { The value of } \\
\text { counterfeit products }\end{array}$ & 5.7018 & 1.85334 & 0.705 & 0.8251 & 0.8027 & \\
\hline & $\begin{array}{l}\text { Previous experience } \\
\text { of buying counterfeit } \\
\text { goods }\end{array}$ & 5.8509 & 1.60524 & 0.677 & 0.6835 & 0.5193 & \\
\hline $\begin{array}{l}\text { intention to buy } \\
\text { counterfeit } \\
\text { goods }\end{array}$ & $\begin{array}{l}\text { intention to buy } \\
\text { counterfeit goods }\end{array}$ & 19.6754 & 5.61464 & 0.837 & 0.843 & 0.752 & 51.213 \\
\hline
\end{tabular}

Table3: Factor reliability and validity check list

\begin{tabular}{|c|c|c|c|c|c|c|c|c|c|c|c|c|}
\hline possession-defined success & .711 & $* *$ & & & & & & & & & & \\
\hline $\begin{array}{l}\text { acquisition as the pursuit of } \\
\text { happiness }\end{array}$ & $.424 * *$ & .708 & & & & & & & & & & \\
\hline acquisition centrality & .581 & .483 & .702 & & & & & & & & & \\
\hline $\begin{array}{l}\text { actively benefiting from } \\
\text { illegal activities }\end{array}$ & .190 & $.254 *$ & $.234 *$ & .794 & & & & & & & & \\
\hline benefiting behavior & $.401 * *$ & $.318 * *$ & .199 & $.537 * *$ & .716 & & & & & & & \\
\hline no harm activities & $.327 * *$ & .215 & -.240 & .492 & $.425 * *$ & .734 & & & & & & \\
\hline appearance care & $.445^{* *}$ & $.432 * *$ & .206 & .115 & $.323^{* *}$ & $.358 * *$ & .756 & & & & & \\
\hline achievement care & .200 & .286 & $-.258 *$ & -.204 & .149 & $.464 * *$ & $.454 * *$ & .719 & & & & \\
\hline $\begin{array}{l}\text { Consumers' attitudes } \\
\text { towards law and order }\end{array}$ & .191 & $.237^{*}$ & -.187 & -.047 & .042 & .115 & .061 & $.211 * *$ & .821 & & & \\
\hline $\begin{array}{l}\text { The value of counterfeit } \\
\text { products }\end{array}$ & $.415^{* *}$ & $.488 * *$ & .100 & .054 & $.235^{* *}$ & .079 & $.251 * *$ & $.434 * *$ & .447 & .896 & & \\
\hline $\begin{array}{l}\text { Previous experience of } \\
\text { buying counterfeit goods }\end{array}$ & .154 & $.227 * *$ & -.065 & .053 & .216 & .107 & $.249^{*}$ & $.234 * *$ & $.363 *$ & $.474 * *$ & .720 & \\
\hline $\begin{array}{l}\text { intention to buy counterfeit } \\
\text { goods }\end{array}$ & $.464 * *$ & $.338 * *$ & .043 & .060 & $.200 * *$ & $.440 * *$ & $.143^{*}$ & $.394 * *$ & .109 & $.437 * *$ & .078 & .867 \\
\hline
\end{tabular}

Table 4: Correlation coefficient matrix and average extracting the square root of the variance In the study, we explored the factors which can

\section{Results} affect the purchasing intention among the 
independent variables by the linear regression model. First, we look for independent variables that have influence on the willing to buy counterfeit goods by the hierarchical regression model. Through constantly adding new variables into hierarchical regression model, we can see only five independent variables entered the linear model among the all 11 independent variables.(Table5) They respectively are the value of counterfeit products, achievement care, no harm activities, possession-defined success, acquisition as the pursuit of happiness.

\begin{tabular}{|c|c|c|c|c|c|c|c|}
\hline \multicolumn{8}{|c|}{ Coefficients } \\
\hline & \multirow[t]{2}{*}{ Model } & \multicolumn{2}{|c|}{$\begin{array}{l}\text { Unstandardized } \\
\text { Coefficients }\end{array}$} & \multirow{2}{*}{$\begin{array}{c}\begin{array}{c}\text { Standardized } \\
\text { Coefficients }\end{array} \\
\text { Beta }\end{array}$} & \multirow[t]{2}{*}{ Sig } & \multirow[t]{2}{*}{$\mathrm{R} 2$} & \multirow[t]{2}{*}{$\triangle \mathrm{R} 2$} \\
\hline & & B & Std. Error & & & & \\
\hline \multirow[b]{2}{*}{1} & $\begin{array}{l}\text { possession-defined } \\
\text { success }\end{array}$ & .519 & .167 & .309 & .000 & \multirow[b]{2}{*}{0.143} & \multirow[b]{2}{*}{0.143} \\
\hline & $\begin{array}{c}\text { acquisition as the pursuit } \\
\text { of happiness. }\end{array}$ & .300 & .119 & .197 & .002 & & \\
\hline \multirow{3}{*}{2} & $\begin{array}{l}\text { possession-defined } \\
\text { success }\end{array}$ & .380 & .173 & 0.209 & .001 & \multirow{3}{*}{0.245} & \multirow{3}{*}{0.102} \\
\hline & $\begin{array}{c}\text { acquisition as the pursuit } \\
\text { of happiness. }\end{array}$ & .275 & .119 & 0.169 & .002 & & \\
\hline & no harm activities & .512 & .210 & 0.342 & .000 & & \\
\hline \multirow{4}{*}{3} & $\begin{array}{l}\text { possession-defined } \\
\text { success }\end{array}$ & .408 & .175 & 0.197 & .001 & \multirow{4}{*}{0.328} & \multirow{4}{*}{0.083} \\
\hline & $\begin{array}{c}\text { acquisition as the pursuit } \\
\text { of happiness. }\end{array}$ & .290 & .121 & 0.164 & .018 & & \\
\hline & no harm activities & .435 & .216 & .279 & .000 & & \\
\hline & achievement care & .452 & .112 & .297 & .000 & & \\
\hline \multirow{5}{*}{4} & $\begin{array}{l}\text { possession-defined } \\
\text { success }\end{array}$ & .298 & .178 & .164 & .018 & \multirow{5}{*}{0.504} & \multirow{5}{*}{0.176} \\
\hline & $\begin{array}{c}\text { acquisition as the pursuit } \\
\text { of happiness. }\end{array}$ & .272 & .123 & .153 & .021 & & \\
\hline & no harm activities & .497 & .212 & .246 & .001 & & \\
\hline & achievement care & .370 & .114 & .257 & .001 & & \\
\hline & $\begin{array}{l}\text { the value of counterfeit } \\
\text { products }\end{array}$ & .738 & .209 & .407 & .000 & & \\
\hline
\end{tabular}




\begin{tabular}{|c|c|c|c|c|c|c|c|}
\hline \multicolumn{8}{|c|}{ Coefficients } \\
\hline \multirow{2}{*}{\multicolumn{2}{|c|}{ Model }} & \multicolumn{2}{|c|}{$\begin{array}{l}\text { Unstandardized } \\
\text { Coefficients }\end{array}$} & \multirow{3}{*}{$\begin{array}{c}\begin{array}{c}\text { Standardized } \\
\text { Coefficients }\end{array} \\
\text { Beta } \\
309\end{array}$} & \multirow{3}{*}{$\begin{array}{l}\text { Sig } \\
.000\end{array}$} & \multirow[t]{2}{*}{$\mathrm{R} 2$} & \multirow[t]{2}{*}{$\triangle \mathrm{R} 2$} \\
\hline & & B & Std. Error & & & & \\
\hline \multirow[b]{2}{*}{1} & $\begin{array}{l}\text { possession-defined } \\
\text { success }\end{array}$ & .519 & .167 & & & \multirow[b]{2}{*}{0.143} & \multirow[b]{2}{*}{0.143} \\
\hline & $\begin{array}{l}\text { acquisition as the pursuit } \\
\text { of happiness. }\end{array}$ & .300 & .119 & .197 & .002 & & \\
\hline \multirow{3}{*}{2} & $\begin{array}{l}\text { possession-defined } \\
\text { success }\end{array}$ & .380 & .173 & 0.209 & .001 & \multirow{3}{*}{0.245} & \multirow{3}{*}{0.102} \\
\hline & $\begin{array}{l}\text { acquisition as the pursuit } \\
\text { of happiness. }\end{array}$ & .275 & .119 & 0.169 & .002 & & \\
\hline & no harm activities & .512 & .210 & 0.342 & .000 & & \\
\hline \multirow{4}{*}{3} & $\begin{array}{l}\text { possession-defined } \\
\text { success }\end{array}$ & .408 & .175 & 0.197 & .001 & \multirow{4}{*}{0.328} & \multirow{4}{*}{0.083} \\
\hline & $\begin{array}{l}\text { acquisition as the pursuit } \\
\text { of happiness. }\end{array}$ & .290 & .121 & 0.164 & .018 & & \\
\hline & no harm activities & .435 & .216 & .279 & .000 & & \\
\hline & achievement care & .452 & .112 & .297 & .000 & & \\
\hline \multirow{5}{*}{4} & $\begin{array}{l}\text { possession-defined } \\
\text { success }\end{array}$ & .298 & .178 & .164 & .018 & \multirow{5}{*}{0.504} & \multirow{5}{*}{0.176} \\
\hline & $\begin{array}{c}\text { acquisition as the pursuit } \\
\text { of happiness. }\end{array}$ & .272 & .123 & .153 & .021 & & \\
\hline & no harm activities & .497 & .212 & .246 & .001 & & \\
\hline & achievement care & .370 & .114 & .257 & .001 & & \\
\hline & $\begin{array}{l}\text { the value of counterfeit } \\
\text { products }\end{array}$ & .738 & .209 & .407 & .000 & & \\
\hline
\end{tabular}

Table 5: Hierarchical stepwise regression results

\begin{tabular}{|l|l|}
\hline hypothesis questions & $\begin{array}{l}\text { Yes or } \\
\text { no }\end{array}$ \\
\hline H1a: Consumers' attitudes towards law and order in respect of counterfeiting have a & no \\
\hline
\end{tabular}




\begin{tabular}{|l|l|}
\hline negative relationship with intention to buy y counterfeit goods. & \\
\hline $\begin{array}{l}\text { H1b: The value of counterfeit products have a positive relationship with intention to } \\
\text { buy counterfeit goods. }\end{array}$ & yes \\
\hline $\begin{array}{l}\text { H1c: Previous experience of buying counterfeit goods have a positive relationship } \\
\text { with intention to buy counterfeit goods. }\end{array}$ & no \\
\hline $\begin{array}{l}\text { H2a: acquisition centrality have a positive relationship with intention to buy } \\
\text { counterfeit goods. }\end{array}$ & no \\
\hline $\begin{array}{l}\text { H2b: acquisition as the pursuit of happiness have a positive relationship with } \\
\text { intention to buy counterfeit goods. }\end{array}$ & Yes \\
\hline $\begin{array}{l}\text { H2c: possession-defined success have a positive relationship with intention to buy } \\
\text { counterfeit goods. }\end{array}$ & Yes \\
\hline $\begin{array}{l}\text { H3a: actively benefiting from illegal activities have a positive relationship with } \\
\text { intention to buy counterfeit goods. }\end{array}$ & no \\
\hline $\begin{array}{l}\text { H3bc:benefiting behavior have a positive relationship with intention to buy } \\
\text { counterfeit goods }\end{array}$ & no \\
\hline $\begin{array}{l}\text { H3d: no harm activities have a positive relationship with intention to buy counterfeit } \\
\text { goods. }\end{array}$ & Yes \\
\hline $\begin{array}{l}\text { H4a: consumer appearance care have a positive relationship with intention to buy } \\
\text { counterfeit goods }\end{array}$ & no \\
\hline $\begin{array}{l}\text { H4b: consumer achievement care have a positive relationship with intention to buy } \\
\text { counterfeit goods }\end{array}$ & Yes \\
\hline
\end{tabular}

Table 6: Result

From the above data processing results, we can see five hypothesis questions have been proved

\section{Discussion}

Through the research we can find which personality traits are more likely to make the purchasing counterfeit decision. The results confirmed that the consumers' attitude towards counterfeit goods will affect the consumers' willingness to buy counterfeit goods and in the same time the result supports the predecessor's research results. But the results also have some different places, according to Viren Swami, Tomas Chamorro-Premuzic , Adrian Furnham's research in Britain,[16] they used the same counterfeit attitude scale. The research results not only showed the value of counterfeit products will influence the intention to buy counterfeit goods, but also consumers' attitudes towards law and order also positive correlated with consciousness. But our studies have not found the existence of this relationship. This may due to the Chinese understanding of counterfeit goods is not the among the previous 11 hypothesis questions, the other six have been not. (Table6)

same as Western. There has mature consciousness of market and intellectual property protection rights in Western, consumers will think the behaviors of purchasing counterfeit is a kind of illegal marketing activity, which can reduce the counterfeit willingness to buy. But in China, the consumer consciousness is weak, the relationship between consumer laws and regulations consciousness and willingness to buy counterfeit is not verified.

The results suggested correlated relationship between consumer materialism values and consumers purchase intention This is consistent with Adrian Furnham, Halldor Valgeirsson's research. But Adrian Furnham found two factors acquisition as the pursuit of happiness and acquisition centrality all can significantly affect the consumers' willingness to buy counterfeit. In our studies haven't confirmed the existence of the this relationship between acquisition centrality with the willingness to buy counterfeit. 
The study found that there is existing relationships between the consumer vanity characteristics and intention to purchase counterfeit. Through qualitative research methods in-depth interviews, Hoe et al found that customers consume the fake well-known commodities instead of buying quality goods, still can bring self expression utility as quality goods consumption can. [17] But in Wen-Bin Chiou, Ying-Hsien Chao's research, consuming fake phone will reduce the self assessment. Why consumers vanity trait in achievement appearance can affect consumer willingness to buy counterfeit good, but appearance have no effect care. This question is worth to explore.

Home and abroad study have confirmed that consumer ethical beliefs have positive relationship with intention to buy counterfeit goods. Taiwan scholars Lu Zhi-zhong and Lu Yan-nit use the same consumer ethical scale which develops by Muncy\&Vitell. The study showed that consumer ethical beliefs have significant influence on purchasing counterfeit product behaviors. The people whose evaluation about benefiting behavior is lower will never buy counterfeit goods. Our study didn't find this phenomenon. But our study find that consumer whose evaluation about no harm activities is higher, his possibility to buy counterfeit products is bigger. The reason may be that Chinese consumers do not think consumption of counterfeit goods can cause certain harm on social organization.

And because the main counterfeit objects in China is foreign well-known brand, consumers based on national center socialist may be holding the idea that consuming the counterfeit goods of foreign well-known brand which made by domestic enterprises is support power on domestic enterprise. For examining the accuracy of this, we need to have further research.

\section{Acknowledgement:}

This paper is supported by the research projects of humanities and social science youth foundation of Chinese Ministry of Education. (11YJC630271)

\section{References}

[1]Goutam Chakraborty, Anthony T. Allred, Terry Bristol, Exploring consumers' evaluations of counterfeits: the roles of country of origin and ethnocentrism.
[J]Advances in Consumer Research, 1996, $23,379-384$.

[2]Daniel C.K. Chow, counterfeiting and china's economic development[EB/OL].The Ohio State University College of Law ,2006http://www.uscc.gov/hearings/2006hearin gs/written_testimonies/06_06_08wrts/06_06_7_8_c how_daniel.pdf

[3] G. Tom, B. Garibaldi, Y. Zeng, J. Pilcher, Consumer demand for counterfeit goods. [J]. Psychology \& Marketing,1998, 15( 5), 405-421

[4] Albers-Miller, Nancy. D, Consumer Misbehavior: Why People Buy Illicit Goods[J].Journal of Consumer Marketing.1999,16(3),273-287.

[5]Kenneth K. Kwong, Oliver H. M. Yau, Jenny S. Y. Lee, Leo Y. M. Sin et al, The Effects of Attitudinal and Demographic Factors on Intention to Buy Pirated CDs: The Case of Chinese Consumers [J].Journal of Business Ethics 2003,47(3),223-235

[6]Wang Fang, Hongxia Zhang, Hengjia Zang et al, Purchasing Pirated Software: An Initial Examination of Chinese Consumers [J].Journal of Consumer Marketing,2005, 22(6):340-351.

[7]Elfriede Penz, Wirtschaftsuniversität Wien,Barbara Stöttinger et al, Forget the "Real" Thing-Take the Copy! An Explanatory Model for the Volitional Purchase of Counterfeit Products [J].Advances in Consumer Research ,1998,32, 568-575.

[8] Furnham, Valgeirsson, The effect of life values and materialism on buying counterfeit products [J].The Journal of Socio-Economic $s$, 2007,36(5), 677-685 .

[9] Wee, Chow-Hou, Soo-Jiuan Tan, Kim-Hong Cheok. Non-Price Determinants of Intention to Purchase Counterfeit Goods .An Exploratory Study [J] .International Marketing Review,1995, Richins, Marsha L, Dawson.Scott, consumer values orientation for materialism and its measurement: Scale development and validation [J].Journal of Consumer Research, 1992,19(3),303-316.

[10]Tan,Benjamin. Understanding Consumer Ethical Decision Making With Respect to Purchase of Pirated Software. $[\mathrm{J}]$.Journal of Consumer Marketing 
2002,19(2):96-111

[11]Trevor $\mathrm{T}$ Moores, Jerry Cha-Jan Chang,Ethical Decision Making in Software Piracy: Initial Development and Test of a Four-Component Model [J]. MIS Quarterly $\&$ The Society for Information Management 2006,30(1):167-80.

[12]Amit Poddar, Jeff Foreman, Syagnik Banerjee et al Exploring the Robin Hood effect: Moral profiteering motives for purchasing counterfeit products [J]. Journal of Business Research, 2012, 65(4), 453-478 .

[13]Scott J. Vitell , James Muncy. Consumer Ethics: An Emperical investigation of factors influencing ethical judgments of the final consumer[J].Journal of Business Ethics, 1992,11(8),585-597

[14]Netemeyer.Richard G., Durvasula.Srinivas, Lichtenstein, Donald R, A Cross-National Assessment of the Reliability and Validity of the CETSCALE[J], Journal of Marketing Research, 1991,28(3),320-327

[15]Lu Long-quan Vanity and Actual: discussion about Consumer ethical beliefs [J] Environmental Management Research 2009,11(2),82-104.

[16]Viren Swami, Tomas Chamorro-Premuzic, Adrian Furnham, Faking it: Personality and individual difference predictors of willingness to buy counterfeit goods[J] Journal of Socio-Economics Volume. 2009,38( 5), 820-825

[17]Hoe, Lee, Gillian Hogg, Susan Hart. ,Faking It: Counterfeiting and Consumer Contradictions. [J] .European Advances in Consumer Research 2004,(6),60-67. 